\title{
MANAJEMEN TATA KELOLA LINGKUNGAN DENGAN MODEL SIMULASI TERPADU PERLINDUNGAN HUKUM KAWASAN PESISIR NUSA PENIDA (PELIBATAN ELITE DESA ADAT SEBAGAI EQUILIBIRIUM)
}

\author{
Ni Ketut Sari Adnyani \\ Email: niktsariadnyani@gmail.com
}

\begin{abstract}
ABSTRAK
Pengelolaan kawasan bahari secara potensial, belum diimbangi oleh sistem pengelolaan yang mampu menjaga keseimbangan ekosistem laut. Hal ini disebabkan dalam perkembangannya terjadi berbagai permasalahan karena pengelolaan kawasan pesisir Nusa Penida dengan aktifitas melaut, seperti mencari ikan dilaut, budidaya rumput laut dan pariwisata ternyata juga mempengaruhi keberlangsungan ekosistem yang ada di bawah laut. Gangguan fisik tersebut dapat diamati di Nusa Penida adalah pecahnya karang karena terlalu seringnya perahu-perahu wisata menancapkan jangkarnya, penggunaan teknologi yang merusak, seperti potassium cyanide, bom ikan, muro ami dan lain-lain. Tanpa disadari limbah industri pariwisata juga berdampak pencemaran lingkungan laut. Tujuan penyusunan artikel ini, yaitu: untuk mengetahui upaya aparatur adat Nusa Penida terkait melakukan upaya legitimasi secara formal dalam bentuk kodifikasi peraturan adat yang mengakomodasi aspirasi elite desa adat pesisir Nusa Penida. Metode dan desain penelitian berupa rancangan pemodelan sistem simulasi terpadu, Pengaruhnya segala bentuk tata potensi hasil laut dapat dilakukan dengan ramah lingkungan. Hasil penelitian, Keberadaan elite desa adat dalam menetapkan aturan serta kepatuhan terhadap aturan warga desa adat setempat sangat mendukung pengelolaan kawasan konservasi perairan berjalan dengan baik. Keberhasilan Elite Desa Adat dalam pemngembangan human resource management didalam program pembangunan kemaritiman, tercapainya sasaran terhadap pembangunan kelautan , kepuasaan dari berbagai pihak atas dibangunnya dermaga baik dari segi pembangunan, keberhasilan, maupun dari segi pemanfaatan secara berkelanutan.
\end{abstract}

Kata Kunci: Human Resource Management, Nusa Penida, Pesisir, Elite Desa Adat.

\section{PENDAHULUAN \\ Latar Belakang}

Berdasarkan hasil observasi di lapangan, pada kawasan pesisir Nusa Penida masih dijumpai aktifitas Elite Desa Adat yang membantu suami sebagai petani rumput laut, pedagang ikan, dan pengelola kawasan wisata bahari. Peran Elite Desa Adat ini sangat menunjang pemenuhan taraf kesejahteraan keluarga. Budidaya komoditas kelautan yang dikembangkan di Nusa Penida adalah rumput laut, dengan jenis Eucheuma spinosum dan E. cottoni. Pada kawasan pesisir Nusa Penida, budidaya rumput laut tetap dilakukan di beberapa tempat dengan lokasi di Desa Suana, Batununggul, Kutampi, Ped, dan Kampung Toyapakeh, dengan beberapa alasan yaitu (1) mempunyai potensi yang sangat cocok untuk budidaya rumput laut, (2) usaha budidaya rumput laut tidak terlalu sulit pemeliharaannya dan dapat dilakukan oleh setiap nelayan, (3) usaha budidaya rumput laut memperluas kesempatan berusaha dan membuka lapangan kerja yang pada gilirannya meningkatkan pendapatan masyarakat pesisir Nusa Penida, terutama masyarakat nelayan, (4) komoditi rumput laut mempunyai peluang ekspor sebagai bahan baku industri pengolahan, (5) sumbangan rumput laut cukup besar terhadap total pendapatan daerah Kabupaten Klungkung, sebagai wilayah administratif dari Nusa Penida sehingga memberikan peran dalam meningkatkan Pendapatan Asli Daerah (PAD) dan (6) sebagai salah satu alternatif bagi masyarakat pesisir Nusa Penida dalam 
pengembangan ekonomi swadaya berbasis kerakyatan.

Permasalahan yang kemudian berkembang bahwa pengelolaan kawasan bahari secara potensial, belum diimbangi oleh sistem pengelolaan yang mampu menjaga keseimbangan ekosistem laut. Hal ini disebabkan dalam perkembangannya terjadi berbagai permasalahan karena pengelolaan kawasan pesisir Nusa Penida dengan aktifitas melaut, budidaya rumput laut dan pariwisata ternyata juga mempengaruhi keberlangsungan ekosistem yang ada di bawah laut. Kondisi tersebut menunjukkan terjadi ancaman terhadap sumberdaya pesisir, hal ini dapat dikaji dari pandangan beberapa pakar, diantaranya: ekosistem terumbu karang yang ada di wilayah Asia Tenggara merupakan yang paling terancam di dunia. Besarnya ketergantungan manusia terhadap sumberdaya laut di seluruh Asia Tenggara telah menyebabkan eksploitasi yang berlebih sehingga banyak terumbu karang yang terdegradasi, khususnya di dekat pusat kepadatan penduduk. Sekitar $70 \%$ penduduk di kawasan ini hidup di sekitar $50 \mathrm{~km}$ pesisir. Perkembangan pariwisata juga mendorong kerusakan terumbu karang. Hal ini terbukti dari penelitian di Indonesia menunjukkan telah terjadi kecenderungan pengumpulan kerang dan specimen karang yang indah secara besar-besaran untuk bisnis souvenir. Demikian juga halnya gangguan fisik lainnya yang dapat diamati di Nusa Penida adalah pecahnya karang karena terlalu seringnya perahu-perahu wisata menancapkan jangkarnya. Penyebab utama kerusakan terumbu karang adalah oleh aktivitas manusia (anthropogenic impact), misalnya melalui tangkap lebih (over-exploitation) terhadap hasil laut, penggunaan teknologi yang merusak, seperti potassium cyanide, bom ikan, muro ami dan lain-lain. Tanpa disadari limbah industri pariwisata juga berdampak pencemaran lingkungan laut.

Ditinjau dari segi ekonomi dan sosial, pengerusakan karang ini akan menurunkan pendapatan dan kesejahteraan masyarakat. Karena dengan rusaknya ekosistem terumbu karang maka akan berdampak terhadap terjadinya ketidakseimbangan ekosistem bahari apabila hal tersebut terjadi juga akan berdampak bagi terhambatnya pembangunan di daerah yang bersangkutan.

Menyikapi problematika di atas, peran Elite Desa Adat Nusa Penida dibutuhkan sekali dalam peran sertanya mengelola sumber daya alam hayati bahari secara produktif. Selama ini kita ketahui bersama dengan budaya purusa (sistem patriarki) yang berkembang di Bali juga mempengaruhi peran Elite Desa Adat di setiap aspek kehidupan. Berdasarkan fakta, dalam pengelolaan sumber daya bahari ikan tangkap, budidaya rumput laut, dan pariwisata Elite Desa Adat Nusa Penida hanya sebatas tenaga operasional yang berkapasitas membantu suami selepas melaut dengan menjual hasil tangkapan ikan, ikut serta dalam proses pembibitan sampai panen, dan menjual hasil panen rumput laut, serta ikut sebagai pengelola kawasan wisata. Peran Elite Desa Adat tidak penuh dan belum mampu diberdayakan secara lebih produktif dalam manajemen tata kelola usaha, pemasaran, maupun produksi yang berbasis industri rumahan. Menyikapi permasalahan kesenjangan ekonomi dan pengentasan ekonomi kawasan termarjinalkan, berdasarkan hasil wawancara dengan responden yang dalam hal ini di wakili oleh pengurus PKK Desa Kuntampi Kaler, bahwa Elite Desa Adat memiliki keinginan untuk mengembangkan keterampilan sehingga dapat membantu kaum laki-laki dalam pengelolaan manajemen usaha termasuk manajemen pengelolaan lingkungan kawasan pesisir Nusa Penida sebagai ladang mencari nafkah yang perlu tetap dijaga kelestariannya secara kontinyuitas.

Hal ini selaras dengan ketentuan yuridis, lingkungan merupakan komponen yang harus selalu dilindungi sesuai amanat konstitusi sebagaimana tercantum dalam pasal 28 ayat (1) UUD 1945, sehingga dalam setiap kegiatan yang berkaitan dengan lingkungan haruslah memperhatikan perlindungan dan peningkatan lingkungan guna terjaganya kelangsungan ekosistem. Upaya menjaga kelangsungan daya dukung sumberdaya alam pesisir dan laut Nusa Penida 
sangatlah tergantung dari komitmen semua elemen masyarakat dan pemangku kebijakan yang berkepentingan di Nusa Penida. Komitmen bersama untuk menjaga sumberdaya alam merupakan nilai-nilai yang diwariskan secara turun temurun akan menjadi sebuah roh pengelolaan lingkungan yang lebih bijaksana. Nilai-nilai ini akan termanifestasi dari pikiran, sikap, dan perilaku masyarakat setempat dalam memandang, mengelola, dan melestarikan lingkungannya.

Langkah yang pernah dilakukan oleh Elite Desa Adat Nusa Penida, yaitu mengembangkan softskill melalui pelatihan Budidaya Kelautan yang difasilitasi oleh Tim Ahli Budidaya Kelautan Fakultas MIPA Universitas Pendidikan Ganesha. Namun, kegiatan yang berselang selama 10 hari belum sepenuhnya mengcover permasalahan pengelolaan lingkungan bahari yang perlu sentuhan tangan Elite Desa Adat untuk pengelolaan secara berdaya guna dan bermanfaat dengan tetap memperhatikan aspek kelestarian ekologi bahari.

\section{Perumusan Permasalah (Statement of Problem)}

Kajian prihal kemaritiman sudah pernah dikaji oleh peneliti sebelumnya, akan tetapi peneliti mengkajinya kembali dengan sudut pandang yang berbeda dikarenakan oleh tinjauan yang peneliti lakukan ada beberapa ketentuan di atas yang belum menunjukkan kiprah Elite Desa Adat dalam pengelolaan potensi bahari, walaupun sudah ada tapi masih terbatas. Jadi ke depannya akomodasi peran Elite Desa Adat lebih diintensifkan dengan mengakomodir aspirasi Elite Desa Adat bersuara melalui aliansi penggiat gender perwakilan dari kaum Elite Desa Adat Nusa Penida sehingga bisa memperoleh perhatian dalam mewujudkan human resource management dalam menunjang ekologi bahari.

Berdasarkan pada uraian di atas, maka untuk mengetahui keterkaitan antara beberapa komponen yang terlibat dalam kaitannya dengan human resource management Elite Desa Adat Nusa Penida dalam pengelolaan ikan tangkap, pengembangan budidaya rumput laut dan pengembangan kegitan pariwisata bahari terhadap kerusakan terumbu karang, sehingga diperlukan suatu metode analisis untuk mengetahui seberapa besar pengaruh human resource management Elite Desa Adat Nusa Penida pada kegiatan pelestarian ekologi bahari yang ada melalui analisis sistem dan pemodelan dengan melakukan simulasi laboratorium terpadu, dengan mengkorelasikan antara pengelolaan sumberdaya alam hayati bahari secara tepat guna untuk menunjang ketahanan pangan masyarakat kawasan pesisir Nusa Penida.

\section{Pertanyaan/Tujuan Penelitian}

Beberapa pertanyaan penelitian yang dapat penulis munculkan dalam kaitannya dengan statement of problem, Bagaimanakah upaya aparatur adat Nusa Penida terkait melakukan upaya legitimasi secara formal dalam bentuk kodifikasi peraturan adat perlindungan hukum kawasan pesisir?

\section{Kelogisan (Rationale)}

Urgensi dilakukannya penelitian yaitu, human resource management Elite Desa Adat Nusa Penida dalam hal pengelolaan lingkungan laut untuk menunjang ekologi bahari, jadi ada pembalikan cara berpikir dari masyarakat adat Nusa Penida bahwa bukan kaum laki-laki saja yang dapat berperan dalam pengelolaan lingkungan, tetapi Elite Desa Adat juga berhak dengan pemberdayaan melalui pengembangan keterampilan secara proporsional dalam bidang manajemen sumberdaya manusia, usaha, tata kelola lingkungan, dan pemasaran yang diperoleh dari pengembangan softskill.

\section{METODOLOGI \\ Jenis Penelitian}

Jenis penelitian ini mengarah pada penelitian lapangan (field research). Adapun jenis data yang telah peneliti amati dan dilakukan pengkajian dalam penelitian adalah berfokus pada keberlangsungan human resource management Elite Desa Adat Nusa Penida dalam menunjang ekologi bahari. 


\section{Rancangan Penelitian}

Rancangan yang digunakan di dalam penelitian ini adalah sosiolegal research. Berdasarkan pada sistem dan pemodelan terpadu yang akan dibangun, maka perlu dilakukan identifikasi terhadap indikator human resource management, seperti softskill dalam pelestarian lingkungan laut oleh Elit Desa Adat Nusa penida.

\section{Analisa Data}

Analisa sistem terpadu didasarkan pada penentuan informasi yang terperinci yang dihasilkan selama tahap demi tahap proses. Tahapan analisa sistem terpadu meliputi : kebutuhan dasar, analisa kebutuhan, persyaratan kebutuhan, formulasi kebutuhan, identifikasi system, input output serta rekayasa awal model dan diagram alir diskriptif.

\section{PEMBAHASAN}

\section{Upaya Aparatur Adat Nusa Penida terkait Upaya legitimasi secara Formal dalam bentuk Kodifikasi Peraturan Adat tentang Perlindungan Hukum Kawasan Pesisir}

Ada empat prinsip dasar pada penegakan hukum yaitu : (1)Hukum adalah perjanjian pada seperangkat aturan yang tujuannya harus dianggap sebagai keinginan dan didukung oleh individu dan masyarakat secara keseluruhan. Pada umumnya, hukum bertujuan untuk mempromosikan "kebiasaan baik." Hukum bisa dilaksanakan lebih baik dan lebih efektif jika individu memahami dan menghargai alasan adanya hukum. (2) Pemasaran dan pendidikan tentang hukum pesisir. 'Menjual hukum' sangat penting untuk meningkatkan kepatuhan sukarela. Orangorang akan jauh lebih mematuhi aturan jika mereka (a) menyadari bahwa aturan itu ada, (b) mampu memahami, dan setuju dengan, alasan yang mendasari aturan, dan (c) menyadari bahwa akan ada konsekuensi jika mereka melanggar aturan itu. Orang harus disadarkan mengapa hukum tersebut ada, serta konsekuensi dari tindakan merekajika mereka melanggarnya. (3)Hukuman yang tepat harus dilaksanakan untuk mencegah perilaku ilegal. Penuntutan terhadap pelanggar yang terbukti secara hukum adalah penting. Proses penuntutan peradilan berfungsi sebagai alat untuk mengubah perilaku. (4) Faktor sosial budaya harus dipertimbangkan dalampelaksanaan hukum. Atribut budaya khusus, seperti yang kadang-kadang bersifat sangat pribadi tentang hubungan antara penegak dan pelanggar, dan faktor-faktor seperti "kehilangan muka" dan menghindar dari penghinaan publik, harus dipahami dan dimasukkan ke dalam rancangan pendekatan penegakan

Keberadaan aturan serta kepatuhan terhadap aturan tersebut akan mendukung pengelolaan kawasan konservasi perairan berjalan dengan baik. Semua perencanaan dan desain pengelolaan kawasan hanya akan berjalan efektif jika ada kepatuhan terhadap hukum. Sumberdaya alam sangat rentan terhadap degradasi oleh eksploitasi, apalagi dengan motivasi masyarakat untuk alasan ekonomi dan bertahan hidup. Dengan adanya aturan yang ditegakkan maka akan meminimalisir pelanggaran dan meminimalisir tingkat kerusakan sumberdaya.

Dasar hukum yang mewajibkan perlunya dilakukan pemantauan kawasan pesisir, yakni Peraturan Pemerintah No. 7 tahun 1999 tentang Pengawetan Jenis Tumbuhan dan Satwa (Pasal 8-11), PP No. 28 Tahun 2011 tentang pengelolaan kawasan pelestarian alam dan kawasan suaka alam (Pasal 26), PP No.60 tahun 2007 tentang Konservasi sumberdaya ikan, Permen KP No.2 tahun 1999 tentang Tata cara penetapan, dan Permen KP No.30 tahun Rencana Pengelolaan dan Zonasi Kawasan Konservasi Perairan.

Aturan lebih lanjut yang menjadi acuan kegiatan pemantauan yang dilakukan, yakni Kepmen Lingkungan Hidup (LH) No.04 tahun 2001 tentang kriteria baku kerusakan terumbu karang, Kepmen LH No.115 tahun 2003 Pedoman Penentuan Status Mutu Air, Kepmen LH No.51 tahun 2004 tentang Baku Mutu Air Laut, Kepmen LH No. 200 tahun 2004 tentang Kriteria Baku Kerusakan dan 
Pedoman Penentuan Status Padang Lamun.

Dalam Kepmen LH No. 04 tahun 2001 tentang Kriteria Baku Kerusakan Terumbu Karang diuraikan tentang persentase baku untuk menilai kondisi kerusakan terumbu karang. Kriteria rusak buruk jika persentase tutupan karang 0$24,9 \%$, rusak sedang jika tutupan karang berkisar antara 25-49,9\%. Kondisi karang baik jika tutupan karang 50-74,9\% dan baik sekali ketika tutupan karang 75$100 \%$.

UU tentang Lingkungan Hidup No.200 tahun 2004, menjelaskan tentang Kriteria Baku Kerusakan dan Pedoman Penentuan Status Padang Lamun. Kriteria baik kaya/sehat jika persentase penutupan lamun lebih besar sama dengan $60 \%$. Kriteria kurang kaya/kurang sehatng jika persentase penutupan lamun antara $30 \%$ sampai $59.9 \%$. Sedangkan jika tutupan persentase lamun kurang dari $29.9 \%$, maka kondisinya termasuk rusak miskin. Sedangkan kriteria baku kerusakan padang lamun menurut Kepmen LH No.200 jika luas area kerusakan lebih kecil dari 29.9\% termasuk kategori kerusakan rendah, kerusakan dengan luas area antara 30\% sampai $49.9 \%$ masuk kategori kerusakan sedang dan kerusakan sebesar $50 \%$ ke atas termasuk kategori tingkat kerusakan tinggi.

Begitu halnya dengan pengaturan pengelolaan sumber daya pesisir menurut hukum adat berdasarkan Paswara dan Perarem Adat Nusa Penida. Tampaknya kondisi equlibrium antara laki-laki dengan Elite Desa Adat merupakan kulminasi yang akan menjadi tujuan setiap masyarakat termasuk masyarakat Bali. Kondisi ini ditandai dengan semakin luwesnya hukum adat yang berlaku pada masyarakat Bali yang pada mulanya menganut idiologi patriarhi "tulen". Sejalan dengan itu bahwa perubahan dan dinamika merupakan suatu ciri yang sangat hakiki dalam masyarakat dan kebudayaan. Adalah sebuah fakta yang tidak terbantahkan bahwa "perubahan" merupakan suatu phenomena yang selalu mewarnai perjalanan sejarah setiap masyarakat dan kebudayaannya. Tidak ada satu masyarakatpun yang statis secara absolut. Setiap masyarakat senantiasa mengalami transformasi dalam arti waktu, sehingga tidak akan ada satu masyarakatpun yang memiliki potret yang sama, kalau kita cermati dalam alokasi waktu yang berbeda, apakah itu masyarakat modern atau masyarakat tradisional, meskipun dengan laju perubahan yang bervariasi. Masyarakat dan kebudayaan Bali bukanlah suatu perkecualian dalam hal ini. Dengan kata lain, Bali senantiasa mengalami perbubahan dari masa ke masa, bahkan dari hari ke hari. Sebagai sebuah komunitas, dalam masyarakat Bali sendiripun terjadi perbedaan-perbedaan yang sangat menjolok dilihat dari perkembangan dan dinamika masyarakatnya.

Oleh karenanya, pengawasan melibatkan peraturan dan pengawasan terhadap kegiatan penangkapan ikan untuk memastikan bahwa perundangundangan nasional, kondisi akses, dan tindakan pengelolaan yang diamati. Komponen pengawasan dalam pemantauan, pengendalian dan pengawasan atau MCS (Monitoring, Control and Surveillance) memerlukan personil perikanan yang tidak hanya mengumpulkan data untuk aspek pemantauan MCS selama tugas pengawasan mereka, tetapi juga dapat berkomunikasi dengan dan mendidik para pemangku kepentingan yang terlibat dalam kegiatan konservasi partisipatif. Orang ini harus memiliki perlengkapan yang sesuai dan fasilitas, dana operasi dan pelatihan baik untuk mendorong kepatuhan sukarela dan untuk menegakkan hukum bila diperlukan. Pengawasan biasanya merupakan komponen terbesar dan paling mahal untuk didanai. Kegiatan ini sangat penting untuk memastikan bahwa sumber daya tidak dieksploitasi berlebihan, perburuan diminimalkan dan pengaturan pengelolaan dilaksanakan.

Data biofisik bawah air meliputi dua hal utama yakni data bio (hidup) yang meliputi seluruh organisme hidup di bawah air dan data fisika kima air yang meliputi salinitas, visibility, $\mathrm{pH}$ air, suhu, sedimen, dan arus. Dalam kerajaan (kingdom) hewan/Animalia banyak fhylum 
yang terapat di bawah air. Menurut Wikipedia, Hewan atau animal yang kita kenal selama ini merupakan kelompok hewan bersel banyak (Metazoa).

Begitu banyak fauna yang terdapat di dalam air yang tidak akan pernah kita ketahui komposisi dan perubahannya dengan seksama tanpa adanya data yang diperoleh melalui aktivitas pemantauan bawah air. Perubahan kondisi ekosistem di dalam air tidak bisa dilepaskan dari pengaruh aktivitas atau keadaan yang ada di sekitarnya termasuk pada permukaan air. Banyaknya limpasan limbah yang terbawa bersama air sungai yang mengalir ke laut akan berpengaruh terhadap visibility, $\mathrm{pH}$ dan salinitas air laut. Pengaruh terhadap faktor fisik air tersebut selanjutnya akan berpengaruh terhadap kehidupan biota-biota perairan. Demikian pula pengaruh limbah pupuk pertanian yang mengalir sampai di perairan akan menyebabkan pengaruh terhadap biota laut tertentu yang secara langsung mempengaruhi rantai makanan dalam perairan

Biofisik bawah air memiliki keterkaitan satu sama lain sehingga untuk mengetahui laju perubahan dan penyebab perubahan ekosistem dibutuhkan data biofisik dari seluruh komponen yang saling terkait tersebut. Dari data itu pula dapat dirumuskan cara mengatasi atau mencegah sebuah perubahan lingkungan sehingga daya dukung dan keseimbangan lingkungan dapat dipertahankan. Untuk mengukur perubahan maka dibutuhkan data awal atau T0 saat pertama kali pengambilan data dan menjadi acuan seberapa besar perubahan pada saat pengambilan data berikutnya.

Prinsip yang perlu dipegang dalam pengambilan data bawah air adalah pengambilan data awal dan data monitoring harus dilakukan pada posisi yang sama. Penentuan posisi dilakukan dengan menggunakan Global Positioning System atau GPS. Jarak deviasi yang masih dalam batas toleransi maksimal 5 meter. Person yang melakukan pemantauan bisa berbeda, yang terpenting posisi dan metode pemantauan sama. Dengan demikian perubahan bisa terlihat dengan jelas karena objek yang diamati sama.
Seiring berjalannya waktu dan bertambahnya pengetahuan, maka dirasakan pentingnya menjaga kelestarian sumberdaya, yang sesungguhnya sudah terdapat dalam kearifan lokal setiap daerah. Hal ini kemudian disadari ketika kenyataan menunjukkan bahwa telah banyak wilayah Indonesia yang mengalami degradasi lingkungan, dan disisi lain masih banyaknya warga masyarakat yang hidup kekurangan ditengah-tengah kelimpahan sumberdaya alam termasuk sumberdaya alam berpotensi wisata. Hal tersebut kemudian menumbuhkan semangat untuk memproteksi sumberdaya alam melalui seperangkat aturan-aturan yang disepakati bersama. Muncullah kemudian konsep perlindungan kawasan berbasis konservasi yang dikenal dengan kawasan konservasi perairan atau marine protected area (MPA).

Konsep perlindungan kawasan perairan ini lahir dan dibangun berdasarkan kearifan-kearifan lokal suatu wilayah atau daerah. Dan oleh pemerintah pusat kemudian dikuatkan melalui regulasi yang dikenal dengan KKP atau kawasan konservasi perairan. Selain itu, pemerintah pusat juga mendorong pemerintah daerah untuk melakukan hal yang sama yakni membuat kawasan konservasi perairan daerah, dan meminta usulan untuk penetapan KKP di daerah yang belum terbentuk KKP. Sehingga saat ini sudah terdapat beberapa KKP dan KKPD di Nusantara, yang keberadaanya sedikit banyak telah membantu upaya pelestarian sumberdaya.

Keberadaan Kawasan konservasi perairan akan sangat tepat jika dimanfaatkan untuk pengelolaan pariwisata bahari. Ada beberapa keuntungan yang diperoleh sekaligus jika dalam suatu kawasan konservasi dibangun pariwisata berkelanjutan. Pariwisata telah menjadi aktivitas ekonomi penting baik untuk wilayah di dalam KKP maupun sekelilingnya di seluruh dunia. Pariwisata berkelanjutan yang direncanakan dengan baik menciptkan peluang bagi pengunjung untuk belajar mengenai konservasi laut dan menghargai masyarakat lokal dengan budayanya. Pariwisata berkelanjutan dapat 
menghasilkan pendapatan untuk KKP dan masyarakat lokal. Setelah masyarakat lokal merasakan manfaat dari KKP maka mereka kemudian terdorong untuk ikut melestarikan sumber daya alam.

Potensi perikanan yang baik untuk dikembangkan menjadi aktivitas ekonomi berkelanjutan di antaranya budidaya ikan dan rumput laut. Ikan yang bisa dibudidayakan banyak jenisnya tergantung karakteristik wilayahnya serta nilai ekonomis jenis tersebut, misalnya kerapu, bobara/kuwe, dan jenis ikan lainnya termasuk udang, dan kepiting. Dari hasil budidaya perikanan masyarakat akan memiliki pendapatan yang baik dan berkelanjutan. Pengetahuan tentang budidaya ikan akan menjadi alternative yang sangat baik bagi masyarakat nelayan yang selama ini hanya bisa melakukan aktivitas penangkapan ikan.

\section{Penutup}

\section{Kesimpulan}

$$
\text { Wujud }
$$

human resource management peran Elite Desa Adat Nusa Penida dalam bentuk aktualisasi melalui upaya-upaya yang ditempuh untuk melindungi kawasan sempadan pantai dari kegiatan pembangunan kawasan pesisir Nusa Penida.

\section{Saran}

- Kepada Pemerintah Kabupaten Klungkung

Selaku pihak yang memiliki kewenangan untuk memberikan perlindungan hukum terhadap kawasan sempadan pantai, Pemerintah Kabupaten Klungkung melakukan berbagai upaya melalui beberapa tindakan dalam melindungi kawasan pesisir dari kegiatan pembangunan pondok. Upaya Pemerintah Kabupaten Klungkung tersebut dapat dilaksanakan oleh beberapa forum Aliansi Elite Desa Adat Pencinta Lingkungan, Instansi, Tim dan Satuan Kerja yang ada pada Kabupaten Klungkung.

Upaya Pemerintah Kabupaten Klungkung dalam melindungi kawasan sempadan pantai dari kegiatan pembangunan pondok wisata di pesisir Nusa Penida memang tidak dapat dilepaskan pada kegiatan pengaturan tata ruang, menurut ketentuan Pasal 1 angka 9
Undang-Undang Nomor 26 Tahun 2007 tentang Penataan Ruang, menyatakan bahwa:"Pengaturan penataan ruang adalah upaya pembentukan landasan hukum bagi Pemerintah, pemerintah daerah, dan masyarakat dalam penataan ruang."

Upaya untuk memberikan perlindungan hukum melalui proses pengendalian pemanfaatan kawasan sempadan pantai dari pembangunan pondok wisata melalui penetapan perizinan yang dilakukan oleh Kantor Lingkungan Hidup Kabupaten Klungkung tersebut didasarkan pada kewenangnya dalam proses penerbitan salah satu persyaratan izin pembangunan pondok wisata maupun hotel, yaitu dokumen lingkungan dalam bentuk AMDAL dan UPL-UKL.

\section{DAFTAR PUSTAKA}

Agus Romadhon.2014. Sistem Dinamik Pengaruh Budidaya Rumput Laut Dan Jumlah Penduduk Terhadap Degradasi Terumbu Karang (Studi Kasus Pulau Poteran - Madura). Madura: Prodi Ilmu Kelautan Universitas Trunojoyo.

Agussalim. 2014. Foto Praktek Lapang Program Studi IImu Kelautan di Waigeo Raja Ampat, tahun 2014. PPS. Ambon: Unpatti.

Anonim, 2013. Melaksanakan Aturan dan Perundang-Undangan Perikanan. Bahan Ajar Diklat Konservasi (Perikanan Berkelanjutan).

English, S.C. Wilkinson, and v. Baker, 2002. Survey Manual for Tropical Marine Resources, Australia Institute of Marine Science. Townsville.

Lasmawan, W. 2002. Sasih Nembelas sebagai Lembaga Desa Adat dalam Pemerintahan Desa Tradisional Bali. Laporan Penelitian. Singaraja: FKIP UNUD.

Marimin. 2004. Teknik dan Aplikasi Pengambilan Keputusan Kriteria Majemuk.Jakarta: Grasindo.

Murniati, A.\& Nunuk P. 2004. Getar Gender: Elite Desa Adat Indonesia dalam Perspektif Agama, Budaya, dan Keluarga. Magelang: Indonesiatera. 
Prasetia, I Nyoman Dodik. 2010. Struktur Komunitas Terumbu Karang Pulau Serangan Pasca Reklamasi. Jurnal Lingkungan Tropis, Vol.5., No.2., Bandung.

2011. Potensi dan Kondisi Terumbu Karang di Kawasan Wisata Lovina. Jurnal Lingkungan Tropis.Vol.6., No.1.,Bandung.

Windari, Ratna Artha. 2011.Korelasi Yuridis Rencana Tata Ruang Wilayah (RTRWP) terhadap Keajegan Alam Bali. Jurnal Media Komunikasi FIS. Edisi Khusus PPKn Vol.10, No.3, Desember 2011.

http://aguswi-kkp.com/category/karya-tulis/ HYPERLINK "http://aguswikkp.com/"Agussalim Powered by WordPress and theme by gazpo.comAgussalim,Pergeseran Base Line Sumber Daya Pesisir dan Laut. Diakses pada hari Rabu, tgl 16 Maret 2016. Pukul 20:10.

www.menlh.go.id. Kepmen Lingkungan Hidup No. 04 tahun 2001 tentang Kriteria Baku Kerusakan Terumbu Karang.

www.menlh.go.id. Kepmen Lingkungan Hidup No.200 tahun 2004, tentang Kriteria Baku Kerusakan dan Pedoman Penentuan Status Padang Lamun. 